\title{
When Voters and Parties Agree: Valence Issues and Party Competition
}

\author{
Jane Green \\ University of Manchester
}

There has been much talk of valence, consensus or competence politics but little theoretical explanation or empirical investigation of how this has arisen. In this article I argue that British political competition has become competence-based because the major parties and the electorate have converged on the dominant left-right dimension of British voting behaviour. As a result, commonly cited core vote explanations for party polarisation have only limited application. The electorate has converged on left-right issues, narrowing the policy space and the available positional strategies of political parties. A different pattern is found for the issue of Europe, and this is interpreted in light of possible causal mechanisms. The article offers a formal model for a rise in valence politics as parties and voters converge, and the implications are discussed for theories of party competition. I argue in favour of competence and salience-based theories of party strategy in place of a reliance on traditional spatial models.

The term 'valence' was used by Donald Stokes (1963) to illustrate the significance of consensual issues - those issues on which there is agreement on the ends of politics, such as lower crime or economic growth. This is in contrast with position issues, on which voters and parties are divided on the ends of politics (Butler and Stokes, 1969; Stokes, 1985; 1992). Stokes' argument was phrased as a direct challenge to the dominant spatial model of party equilibrium, namely Anthony Downs' (1957) theory of two-party convergence on a normally distributed preference dimension. Stokes' $(1963 ; 1992)$ claim was that valence issues are highly important to party competition and to political choice, and since there is consensus on these issues, parties are instead judged on their performance to deliver. On position issues voters have different ideal points but on valence issues voters have the same ideal point (Enelow and Hinich, 1982). The greater the importance of valence issues, the less spatial models help us understand vote choices and parties' competitive strategies. The term 'valence' has since been used as a proxy for leadership ratings allowing for leverage over electoral strategy (Groseclose, 2001; Schofield, 2004), for candidate trustworthiness and honesty (Enelow and Hinich, 1982) and for economic performance ratings (Whiteley, 1984).

There is good reason to focus more carefully on the concept of 'valence' in order to understand better why and whether valence politics is an apt description of British political behaviour. Three relevant factors have coincided: the significance of judgement or competence ratings to the vote choice (Clarke et al., 2004; Denver, 1994), a decline in the association between left-right position and vote 
choice (Sanders, 1999) and the perceived convergence of the main parties (Bara and Budge, 2001; Endersby and Galatas, 1998; Heath et al., 2001; McLean, 2002). In this article the significance of a fourth empirical factor is revealed and linked to the concept of valence and to a causal theory of valence politics. Party convergence has occurred within a period of gradual consensus among voters on the key left-right dimension of British politics. This electoral consensus, coupled with the convergence on this dimension by parties, logically leads to the scenario described by Stokes in 1963 wherein competition is on valence issues instead of position issues. The consequence is that parties are judged on competence in place of ideological differentiation. Harold Clarke et al. (2004) argue that valence politics has always been crucial to the vote choice, but this article claims that a transition to the presence of 'valence issues' represents a recent characteristic of the British electoral landscape. Increasing consensus, particularly on left-right issues, has important implications for party competition. Not only does such a trend point to the importance of competence evaluations in party choice but it also confounds the arguments that parties are constrained by the more polarised ideological positions of their traditional supporters. For example, many commentators cite the core vote explanation to be the main cause of the Conservative party's electoral difficulties between 1997 and 2005. ${ }^{1}$ Thus, in two respects, the trend revealed in this article provides important information for our understanding of British political competition.

\section{Theory}

A great deal of the academic literature explaining the ideological positions parties adopt arose during the 1970s and 1980s. In this period the two main British parties were clearly differentiated along policy lines (Clarke et al., 2004; Heath et al., 1985; McLean, 1982) and this was a challenge to the traditional Downsian model of party competition (1957) that, in a two-party system, rational parties will converge at the median voter to win the greatest number of votes. Party polarisation in the US and elsewhere has more recently been offered as further evidence to challenge the Downsian model (MacDonald and Rabinowitz, 1998; Schofield, 2003; 2004; Schofield and Sened, 2005).

In order to account for this differentiation the dominant alternative explanation has been that parties are constrained by their existing supporters, because traditional party supporters are motivated by more ideologically divergent opinions. In order to maintain this core support, parties place themselves closer to these voters than the median position allows. ${ }^{2}$ Therefore, according to these 'core vote' or 'activist' theories, the equilibrium position will be midway between the core voter or activist median position and the median voter overall. ${ }^{3}$

However, the recent period of British political competition appears to confirm the Downsian view once again, that parties converge towards the median voter. ${ }^{4}$ This is borne out by the fact that fewer and fewer people now recognise a 
difference between the Conservatives and Labour. This perceived lack of difference may be one of competence or style, or due to lower attention of where the parties stand, but it is probably also one of perceived ideological similarity. Responses in British Election Studies to the question 'Do the Conservatives and Labour differ?' are highly associated with whether respondents place the two parties close together or further away from each other on eleven-point issue scales. ${ }^{5}$ Using British Election Study data and British Social Attitudes data, Catherine Bromley and John Curtice (2002) also reveal that 'Never before have the electorate felt that there was so little to choose between the two main parties' (Bromley and Curtice, 2002, p. 152).

Reasons for party convergence may be varied. British parties may simply be behaving according to Downsian predictions, overcoming the desire to move towards their less representative voters. The two major parties may face growing incentives to converge due to the significance of the third centrist party. Wider trends in leader-centred elections may drive down the incentives to compete ideologically. However, there are strong grounds on which to predict that party supporters no longer present such a trade-off in relation to the location of the median voter, thus, according to core vote or activist theories of party location, allowing parties to converge. This explanation challenges the widely held empirical assumption that party supporters necessarily polarise towards the extreme left and right of the ideological spectrum. ${ }^{6}$ Three trends lend weight to the prediction of voter consensus.

First, we can expect to see lower ideological polarisation as an outcome of partisan de-alignment (Clarke and Stewart, 1984; Clarke et al., 2004; Heath et al., 1991; Aldrich, 1995; Whiteley and Seyd, 2002). As strength of party attachments declines, so we can expect polarisation also to decline, since party identification strength is strongly correlated with ideological polarisation (Heath et al., 2001). Therefore, the greater the proportion of weakly identifying partisans, the more moderate we can expect the electorate to be overall. Stokes (1992) argues that party loyalties were rooted in position issues and so valence politics is correlated with the weakening of these party loyalties. Thus a de-aligned electorate creates incentives for parties to compete at the centre ground, since floating voters and core voters are more likely to be moderate. De-alignment has also been coupled with a melting of traditional social divisions, which may also be expected to increase moderation. Hence Adam Przeworski and John Sprague (1985) highlight the imperative for socially democratic parties to moderate as their working-class base declines as a proportion of the electorate.

Secondly, in order to be electorally successful, party organisations are expected to become electoral-professional (Panebianco, 1988) or catch-all parties (Kirchheimer, 1966), undergoing a process of 'de-ideologisation' and, significantly, a concentration instead upon valence issues. This centripetal tendency is also predicted by Giovanni Sartori (1976) due to the two-partyism found in the UK. Such a transformation to achieve centrist modes of competition has been 
witnessed in the transformation of New Labour. ${ }^{7}$ If the two main parties have undergone such a process of de-ideologisation - for New Labour in the form of making key issues appear consensual (Hindmoor, 2004), and for the Conservatives, jettisoning their Thatcherite reputation, then supporters may follow their parties to the centre ground. Paul Webb and David Farrell (1999) demonstrate such a following of ideological change among Labour party members following the 1995 reforms to the party constitution and Geoffrey Evans and Robert Andersen (2004) illustrate an endogenous relationship between party location and the self-placement of party supporters. It has long been argued that ideological political leadership is highly associated with more ideological voting (Pierce, 1970) and thus the reverse may now be the case. It is also argued that parties shape dimensions of political competition to their advantage $^{8}$ and such an explanation is consistent with an established literature on party cueing (e.g. Zaller, 1992). Thus if the parties have converged we should also expect to find convergence among these parties' supporters, both because centrist parties attract more centrist supporters but also because formerly polarised supporters will moderate their positions in line with the perceived location of their party.

Lastly, it is plausible that some issues simply fail to capture modern political disagreement given the exogenous economic and political environment. For example, questions relating to inflation and employment levels, while in the past highly contentious and viewed as irreconcilable, are now viewed far less as a trade-off in economic terms (McLean and Jennings, 2006). The same can be argued for questions relating to the desired extension of the privatisation of industries. Since many industries were privatised in the 1980s, it makes less sense to position oneself in favour of more privatisation and the issue is now so low in salience that we could expect individuals to hold an ambivalent position.

On the basis of these predicted relationships, the following hypothesis can be offered:

Hypothesis 1. On the left-right dimension, the preferences of individuals identifying with the two main parties will increase in similarity over time.

However, whereas overall party locations appear to have converged, on the issue of European integration differences between the parties have become more pronounced. The Conservatives have adopted a more Euro-sceptic position with greater clarity since 1997 and Labour has adopted a more pro-European position (Evans, 2001; 2002). Institutional arguments have been put forward for the polarisation of the parties on this issue (e.g. Aspinwall, 2004; Forster, 2002), therefore differing from the centripetal expectations on the left-right dimension. Thus, we might expect the electorate and in particular the party supporters of each main party to disagree on the issue of European integration, and with increasing polarisation. Furthermore, unlike the left-right dimension, opinion on Europe tends to be cross-cutting - party supporters are found on the left and 
right of this dimension - and thus the correlation between partisanship and preference should not be as clearly pronounced. Therefore we can predict consensus on the left-right dimension but a more complex and polarising pattern on the issue of European integration, representing the nationalist dimension in British voting behaviour (Heath et al., 1999).

Hypothesis 2. On the issue of European integration, the preferences of individuals identifying with the two main parties will polarise over time.

Furthermore, on both these dimensions, if voter preferences follow party preferences, then we can also expect to find a close relationship between the perceived difference between parties and the observed differences between their voters, leading to hypothesis 3 .

Hypothesis 3. Preference change at the voter level will be closely associated with perceived similarity or divergence at the party level.

The following section outlines the selection of data and methods.

\section{Method}

Preferences were measured using available issue questions included in British Election Studies between 1987 and 2005. Over time analysis is used to examine the change in the difference between mean Labour and Conservative identifiers and also the mean difference between the perceived locations of the Labour and Conservative parties, and cross-sectional analysis is used to examine whether these apparent changes between the party identifiers of the main parties are also evident across the electorate as a whole, including comparison by Liberal Democrat support and among individuals who do not identify with any party.

Data are available for five issue scales in British Election Study cross-sections and panel studies over time. The most consistent issue scales have been in the 1987, 1992, 1997, 2001 and 2005 cross-sections and the 1992-7 and 1997-2001 panel studies. Prior to 1987 there was wide variation in question format and wording. Subsequently, respondents in each case were asked where they would place the parties and themselves, and the wordings of the scales are as follows:

Equalisation of Incomes

$1=$ 'Make much greater efforts to make people's incomes more equal' to $11=$ 'Be much less concerned about how equal people's incomes are'.

Nationalisation or Privatisation

$1=$ 'Nationalise many more private companies' to $11=$ 'Sell off many more nationalised industries'.

Inflation-Unemployment

$1=$ 'Getting people back to work should be the government's top priority' to $11=$ 'Keeping

prices down should be the government's top priority'. 
Tax-Spend

$1=$ 'Government should cut taxes and spend much less on health and social services' to

$11=$ 'Government should increase taxes a lot and spend much more on health and social services'.

EU Integration

Britain should: $1=$ 'Do all it can to unite fully with the European Union' to $11=$ 'Do all it can to protect its independence from the European Union'.

These five issue scales reflect known orthogonal dimensional categories in British voting behaviour (Evans, 1999; Heath et al., 1999). The first four reflect the traditional left-right dimension, and the EU scale reflects a national dimension. Respondent distributions on the first four issues: tax-spend, inflationunemployment, nationalisation and equalisation of incomes are all highly correlated, but far less so with the EU scale. For example, in the 1992 wave of the 1992-7 British Election Panel Study (BEPS), the correlations between these scales are shown in Table 1, demonstrating that the first four messages are highly correlated, but none are highly correlated with the fifth - the question on preferences towards EU integration. Consistent with the dimensionality of these scales, a left-right index is constructed from the first four issues (by summing these scores and taking an average), and this left-right index is used in the time-series comparisons, and compared with the EU scale.

A further issue dimension in British voting behaviour is the libertarianauthoritarian scale (Evans et al., 1996), reflecting attitudes to issues such as morality and law and order. Unfortunately, party and respondent questions were only asked on this scale in the 2001 BES cross-section and therefore it is not possible to construct a time-series of attitudes and party placements. ${ }^{10}$ However, in 2001 the distribution of preferences was strongly consensual. The Conservatives and Labour mean respondent values only differed by 0.59 (from a Conservative identifier mean of 3.33 and a Labour identifier mean of 3.96). ${ }^{11}$ Further attitude questions are asked in the election surveys but these are only asked in relation to respondents rather than for parties and respondents, and they differ in content over time, therefore preventing a comparable analysis of their distribution.

Using the calculated left-right index and the EU scale, consensus is measured in two ways. Where comparisons in the degree of difference are relevant I compare $F$ ratios for the differences between groups. In the time-series analyses, I present the difference in mean scores for Labour and Conservative party identifiers in each point of the time series on the left-right index and EU scale, between 1987 and 2005 (between 1992 and 2005 on the EU scale) and then compare these trends with the placement of the Labour and Conservative parties (the difference in the mean score for each party) on the same scales. In order to calculate the perceived distance between the parties I use the mean perceived party placements among the whole (weighted) BES samples to minimise the likelihood of party 


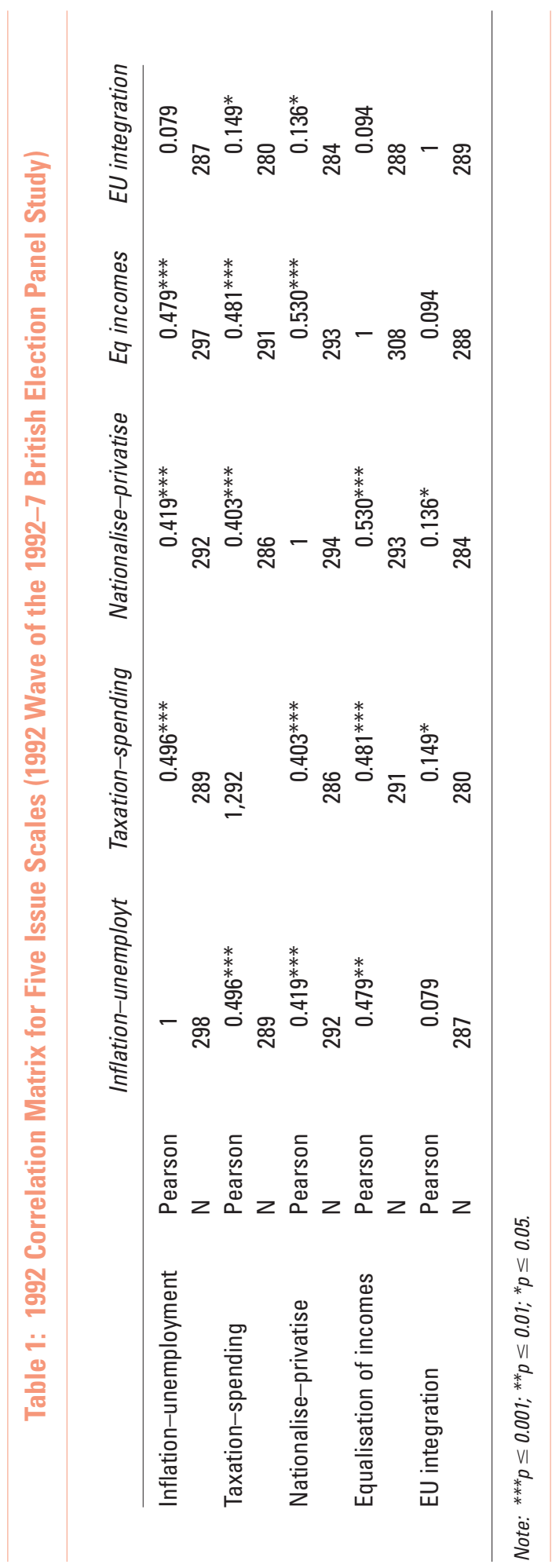


identifiers simply placing their party closest to their own location, due, for example, to bias in perceptions, survey response or selective perception. Furthermore, by using the actual differences in party placement these responses should be less open to partisan bias than the question, 'do the Conservative and Labour parties differ?'.

\section{Voter Consensus over Time}

Figure 1 presents a distribution of preferences on the issue of nationalisation and privatisation in 1987. This is the distribution used by James Adams (2001, p. 67) upon which the author predicts party equilibrium towards the left for Labour and the right for the Conservatives, on the basis of incentives to appeal to the party base. Replicating this figure provides a benchmark of polarisation in the late 1980s against which to compare later consensus. Figure 1 demonstrates that more Labour identifiers supported greater nationalisation than Conservatives, who were more likely to support greater privatisation - thus representing a straightforward dividing line in British politics in 1987. The issue divides the electorate in the way we would predict according to core vote theories of party position. This issue in 1987 is positional, since it divides voters and it also divides the perceptions of the parties. The difference between the mean Conservative and

Figure 1: Preference Distributions by Party Identification on the Issue of Nationalisation (1987 BES Cross-section, $N=3,214$ )

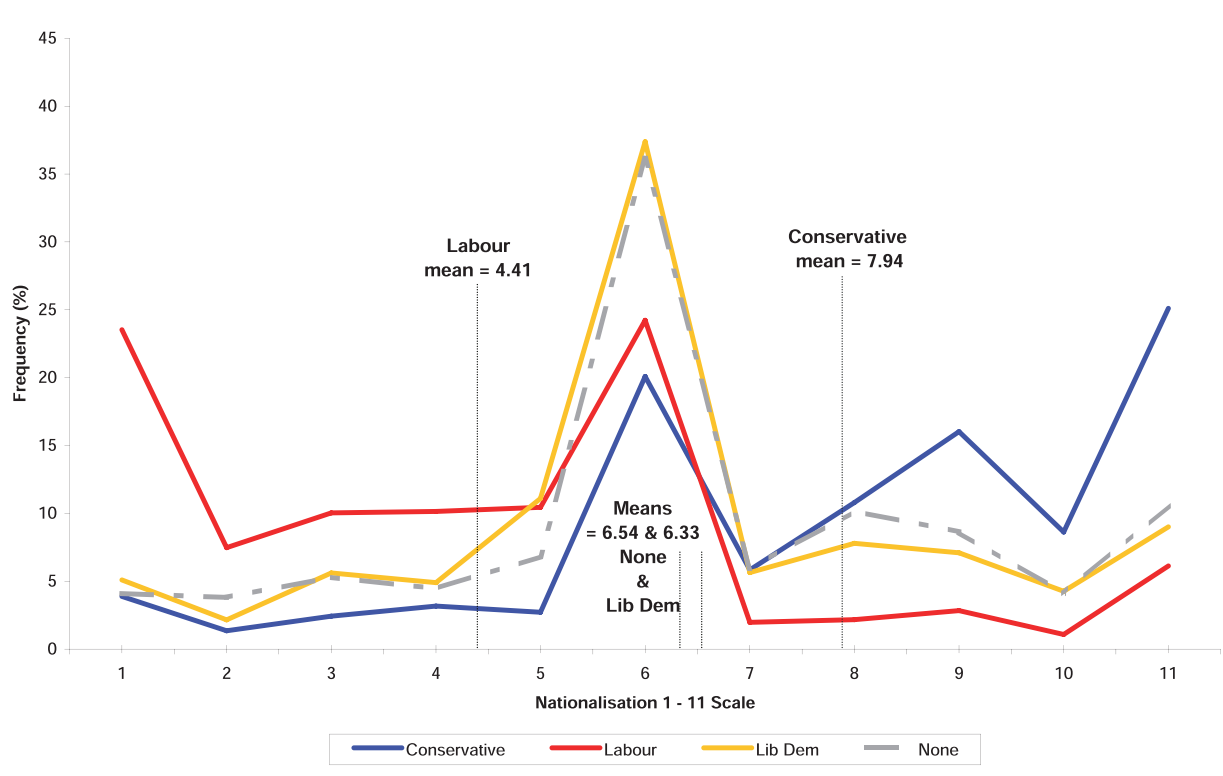

Note: $t=31.22, F=2.2{ }^{* * *}$ between Conservative and Labour. 
Labour supporter position was 3.53. Conservative identifiers had a mean value of 7.94 and Labour identifiers a mean of 4.41. According to Adams (2001), Alliance (the SDP-Liberal Alliance) supporters create some incentive to squeeze votes in the middle, but the parties each reach equilibrium between the centre and their own partisans, therefore polarising.

However, consistent with the predictions made above, particularly in relation to the changing meaning of the scale and the depoliticisation of nationalisation, we would expect this scale to represent a valence distribution in later years. Figure 2 demonstrates that the polarisation witnessed in Figure 1 is no longer evident in 2001. In 2001 we see some partisan differences but these are dramatically reduced. The difference between the mean value of Conservative and Labour partisans was only 1.62. The Conservative mean was 6.10 and the Labour mean was 4.48. Correspondingly, the F value is only 1.87 , significant at the $p<0.001$ level. According to the arguments made by Adams, the equilibrium position of the two major parties should be far closer to the median voter, because the cost of moving away from party supporters is significantly reduced as the relationship between partisanship and ideology weakens. An appeal to the median voter on this issue is more consistent with an appeal to the party's own identifiers.

Figure 2: Preference Distributions by Partisanship on the Issue of Nationalisation (British Election Panel Study, 2001 wave, $\mathbf{N}=1,751$ )

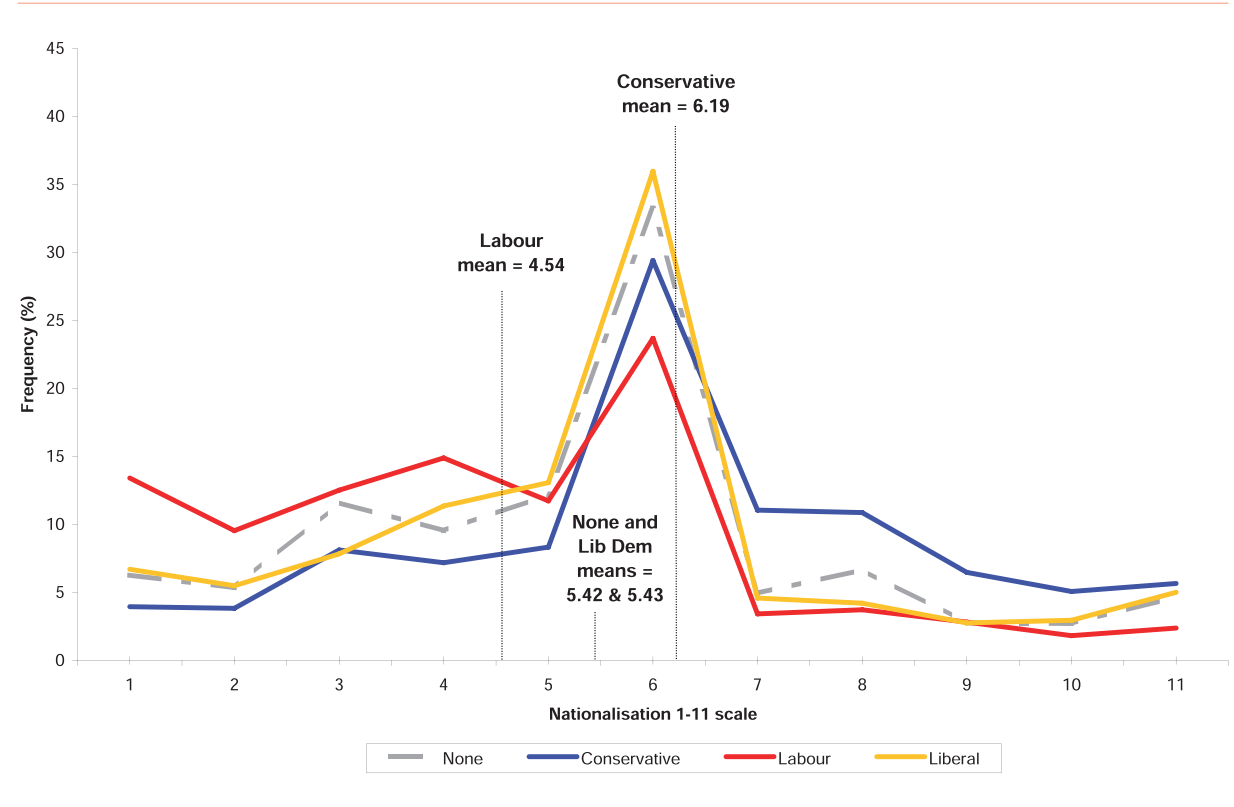

Note: $t=12.103, F=1.867{ }^{* *}$ between Conservative and Labour. 
Furthermore, preferences of the supporters of each group closely mirror each other. On the nationalisation scale the hypothesis appears to be confirmed. A once positional issue is now more accurately described as a valence issue, because far fewer party supporters are divided on the goals of nationalising or privatising more industries. Given the extension of privatisation over the period between 1987 and 2001 (Heath et al., 2001), it is particularly notable that only a small proportion of Labour identifiers are found towards the left of this scale. Furthermore, if more polarised individuals had simply left the party by 2001 we might expect to find some polarisation in the sample. However, all groups of respondents are consensual on this issue in 2001, relative to 1987.

If preferences on all scales comprising the left-right dimension have likewise reduced in polarisation, then we should expect to see the mean distance between Labour and Conservative partisans diminish over time on the combined left-right index, calculated by averaging the four component questions. Figure 3 presents the difference in the Labour and Conservative party identifier mean scores on the left-right index between 1987 and 2005.

The scale is composed of the left-right question and the tax-spend question in 2001 and 2005, and the incline in the mean distance in 2001 may reflect this difference. However, prior to 2001, and again in 2005, the left-right index displays a downward trend from 1987 in the difference between Labour and Conservative

Figure 3: Distance between the Mean Labour and Conservative Identifier on a Composite Left-Right Index between 1987 and 2005 (British Election Studies)

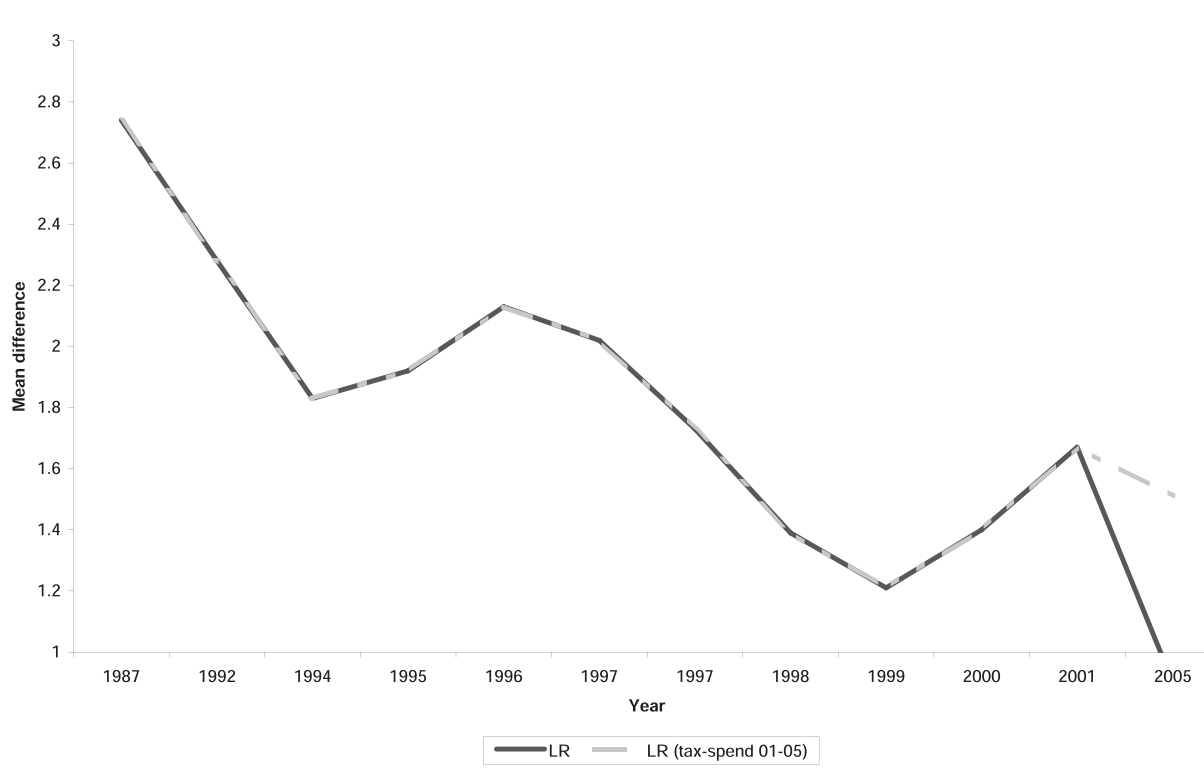


party identifiers' mean values. The dotted grey line represents the difference on the tax-spend scale only since this is the only issue scale available in the 2005 BES cross-section. Between 1987 and 2005 the difference between the Labour identifier mean and the Conservative identifier mean drops from 2.7 to 0.9 and from 2.7 to 1.5 using the latter measure. The underlying issue scales comprising the left-right axis can therefore be expected to represent valence distributions, becoming more consensual.

A cross-sectional analysis of each of the issues bears out this change over time and supports the causal argument that individuals change their positions, rather than simply changing their party support. The tax-spend scale, arguably the most salient of all issues comprising the left-right dimension, demonstrates greater convergence over time among all respondents in each sample. Also, earlier British Election Studies demonstrate greater polarisation on left-right issues between 1964 and 1983 than found on the left-right dimension here in 1987, suggesting the consensus found in 2005 was preceded by a longer period of polarisation than is evident in Figure 3.

Another way of measuring the trend in growing consensus is to compare the variance on the scales in the early years with that in recent elections. If the measured variance declines, there is support for the argument that growing consensus reflects a narrowing of the 'ideological space'. If this has occurred, then the incentives for party divergence have clearly weakened. Party positions will be more convergent because their ability to win votes in divergent positions is greatly restricted, even among their core electoral constituencies. Table 2 presents the mean values and standard deviations for each question comprising the left-right index between 1987 and 2005, and shows that the variance on the scales relevant to the left-right dimension has diminished since 1987. The standard deviations on the combined left-right index have declined from 2.06 in 1987 to 1.44 in 2005, although in 2001 the variance was lower at 1.32. In 2001 and 2005 the variance on the tax-spend and left-right label scales did not change significantly, possibly because they had reached a floor at, respectively, around two standard deviations from the mean. However, the findings suggest that the ideological space among the British electorate has narrowed to a significant degree. Hence the options for party spatial location are restricted. These findings provide further support for the first hypothesis, which predicted that the leftright dimension is now more 'valence' in nature.

However, as outlined above, a different pattern is predicted on the issue of Europe. This tends to be a cross-cutting issue and it has divided the parties in increasing measure (Evans, 1998; Evans, 2002). Therefore, if we have witnessed consensus on the left-right axis, the opposite should be the case on Europe, and we should expect distributions to be more closely related to party support, consistent with the suggested causal direction between party cues and voter preferences. Figure 4 presents the difference between Labour and Conservative identifiers' mean placement scores on this issue between 1992 and 2005 . 


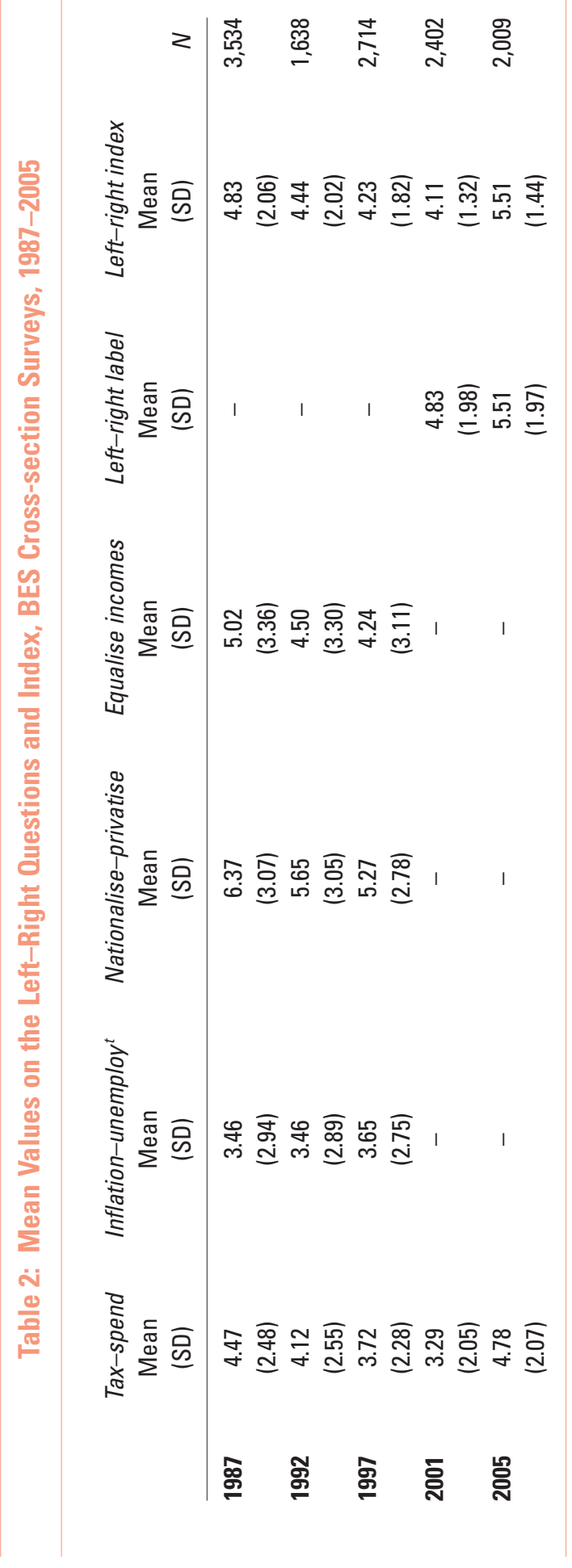


Preferences on the European issue appear to follow a trend away from consensus. The difference between the Labour and Conservative party identifier means is 1.0 in 1992 and 2.1 in 2005. The groups deviate from each other most notably in election years 1997 and again in 2001 (a difference of 2.2 in both years). This pattern seems to suggest that this issue has become more positional over time, consistent with hypothesis 2 , and contrary to the distribution on the left-right dimension in Figure 3. However, the fact that the greatest differences are found in election years may betray a panel artefact in the intervening samples whereby a 'blanding' of attitudes occurs. If so, then the above findings suggest that respondents were located similarly in 1992 but were more greatly polarised in the election years 1997, 2001 and 2005.

However, differences in mean scores alone do not verify the pattern of preferences on a cross-cutting dimension (since a mean of 6.0 could signify polarisation at points 1 and 11 or convergence around point 6). A brief description of cross-sectional data over these time points illuminates the pattern found in Figure 4. These trends are summarised briefly since they are also reported elsewhere (Evans, 1998; 2002; Evans and Butt, 2006).

In 1992, party identifiers of all three major parties were located on both the opposing integration and extending integration ends of the issue scale. This confirms the expectation that preferences cut across party support. The issue was

Figure 4: Distance between the Mean Labour and Conservative Identifier on the EU Scale between 1992 and 2005 (British Election Studies)

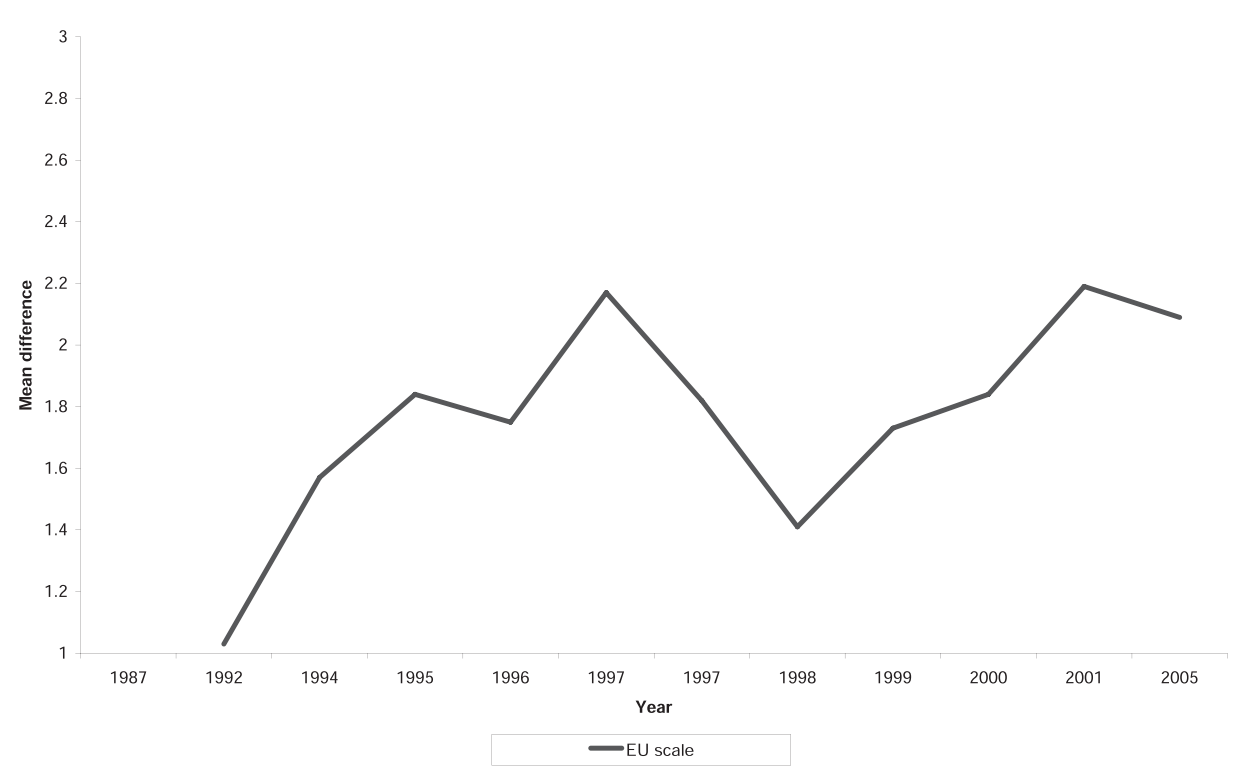


also cross-cutting for respondents who did not identify with a party. In 1997 the issue remained cross-cutting but to a lesser extent. Opinion on the issue shifted towards the right of the scale. In this year 16 per cent of Liberal Democrat identifiers opposed further integration, 20 per cent of Labour identifiers did so and 31 per cent of both Conservative identifiers and identifiers of no party or other parties opposed further integration (1997 BES cross-section, $N=2,617$ ). Therefore the difference in means displayed in Figure 4 hides a shift towards anti-integration attitudes among all party supporters, although this resulted in a greater difference in mean scores between Conservative and Labour identifiers. By 2001 the difference in mean values was also greater but in this survey there was growing consensus that Britain should protect its independence from the European Union. This can be seen in Figure 5.

Although the difference in means is greatest in 2001 (an F ratio of 17.97 in 2001 can be contrasted with an F ratio of 1.19 in 1992), in 2001 the issue reflects greater agreement than in 1997. This underlines previous observations that the electorate shifted to a more Euro-sceptic position over time (Evans and Butt, 2006), consistent with Mark Franklin and Chris Wlezien (1997) and Franklin et al. (1994) who argue that attitudes to Europe responded against a perceived extension of integration.

The 2005 British Election Study contained a slightly different question: whether to stay in or leave the EU. On this question respondents were again divided,

Figure 5: Preference Distributions on the EU Integration Scale by Partisanship (2001, BEPS, $N=1,822$ )

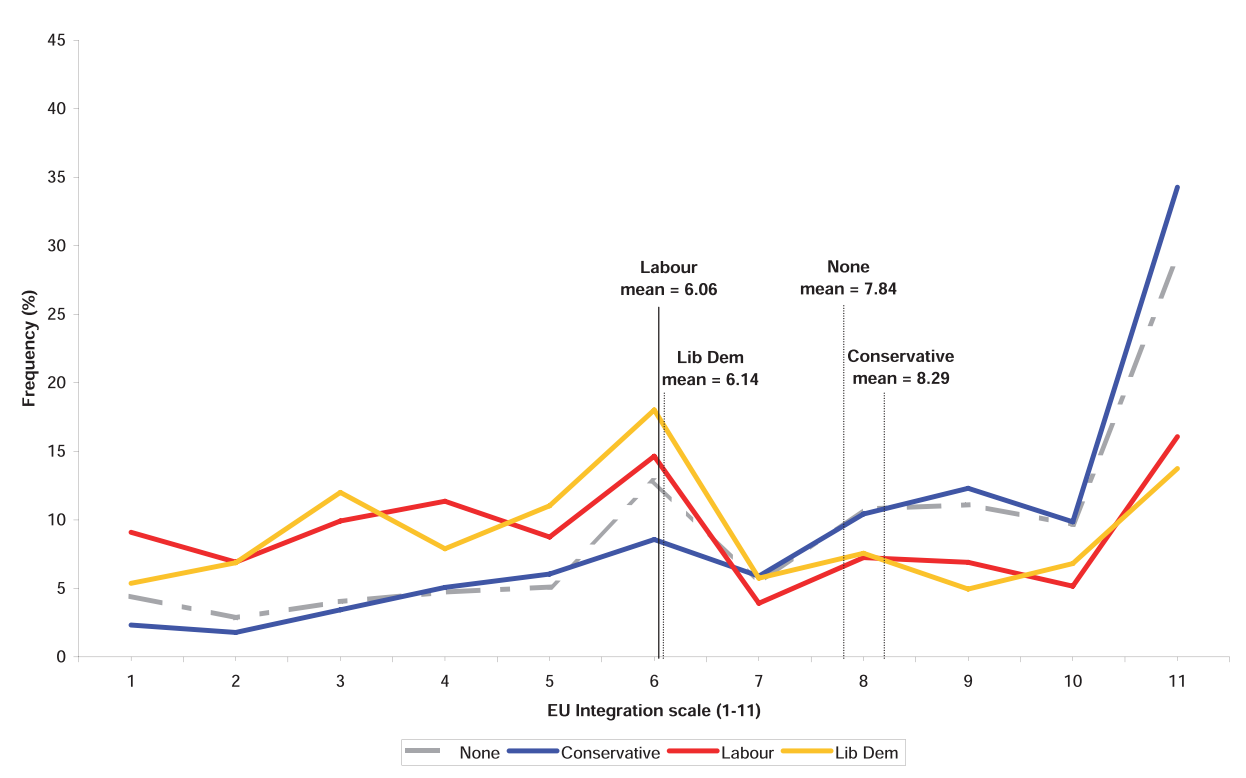


demonstrated by an F value of 12.04, but differences were now more clearly along partisan lines.

Figure 6 shows that for respondents who identified with no party, attitudes were cross-cutting. However, Conservative identifiers were less likely to be found at both ends of the scale in 2005, tending to be mostly in favour of leaving the EU (22 per cent) or adopting a neutral, middle view (15 per cent). Labour identifiers were most likely to be in favour of remaining in the EU (18 per cent) compared with 10 per cent who favoured withdrawal. Supporters of the Liberals remain distributed towards the centre of the scale and to the left of the scale, favouring staying in the EU. The problem in deriving conclusions from these findings lies in the changing wording of questions on European integration. However, it does appear that by 2005 the preferences of party identifiers have become more closely aligned with partisanship, consistent with the increasing polarisation of the parties on the issue (Evans and Butt, 2006). This evidence provides limited support for the second hypothesis that the preferences of individuals identifying with the two main parties will polarise over time. Due to the more complex relationship on the issue in the preceding years, it is not possible to infer a clear trend towards greater polarisation. However, the 2005 data do suggest such a pattern in this one election.

The trade-off between partisans and centrist voters is less acute on the left-right dimension, but the reverse is the case most recently on the issue of Europe. This

Figure 6: Preference Distributions by Partisanship on the Issue of EU Integration (2005 BES Cross-section EU Stay/Leave Scale, $N=2,072$ )

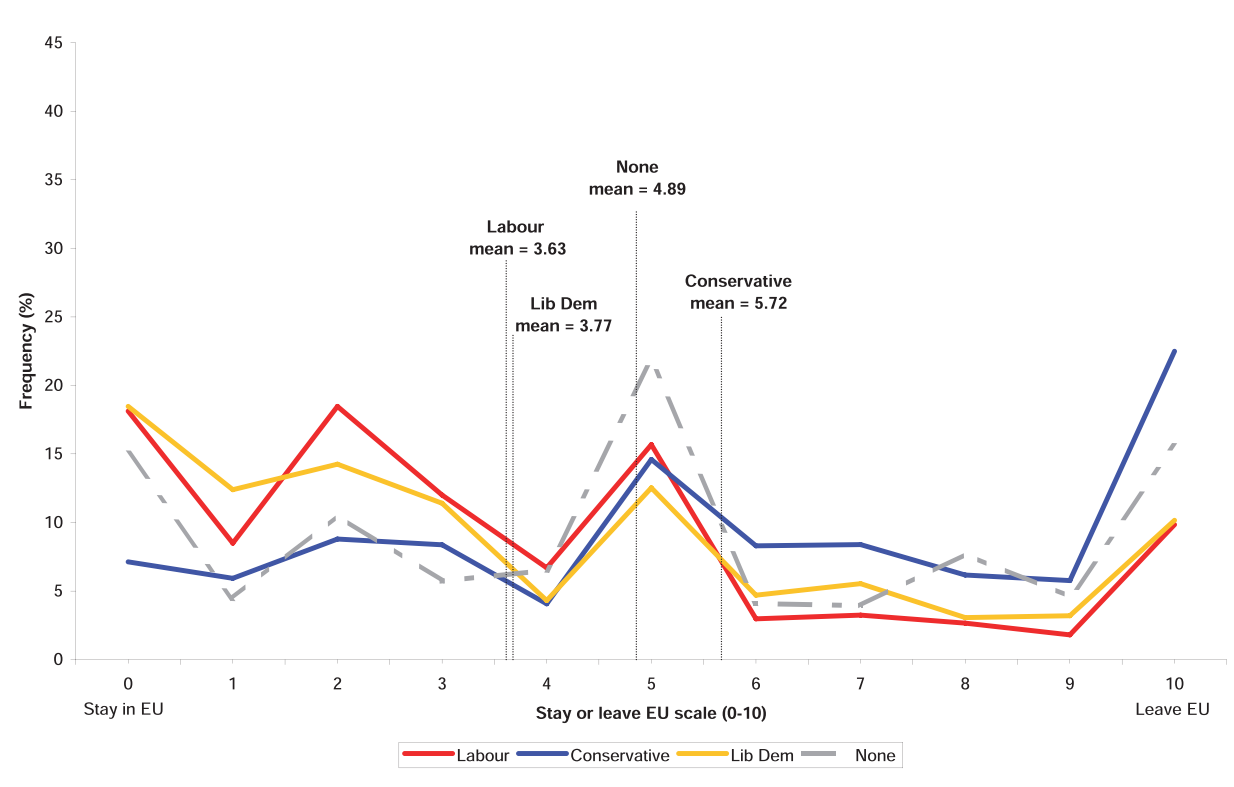

Note: $t=-12.19, F=12.04 * *$ between Conservatives and Labour. 
suggests that any incentives for party divergence on left-right issues have diminished over time. We would therefore expect to see parties converging as their supporters adopt valence distributions on left-right issues, and a reverse trend on the European issue. However, if party supporters follow the cues of their parties, then the assumption of 'constraint' is much weaker. The next section compares the positions of party voters with the perceived positions of the two corresponding main parties, in order to explore the relationship between these evaluations, and to explore the evidence for the third hypothesis, which claimed a close relationship between polarisation and convergence among voters and the two major parties.

\section{Party and Partisan Convergence}

A comparison of voter and party placement is particularly significant within a 'valence politics' theoretical framework. If the electorate represents a valence distribution, agreeing on the goals of politics, but the parties are perceived clearly to disagree, then competition remains positional and politics remains spatially competitive. In order to examine the third hypothesis, that convergence (or divergence) at the voter level will be closely associated with trends at the party level, Figures 7 and 8 present a comparison of perceived party position with the difference between Conservative and Labour identifiers in the same time points. Figure 7 provides the comparison for the left-right index measure.

Figure 7: Comparison of the Mean Distance between Labour and Conservative Partisans and the Perceived Distance between the Labour and Conservative Parties, on the Left-Right Index between 1987 and 2005 (British Election Studies)

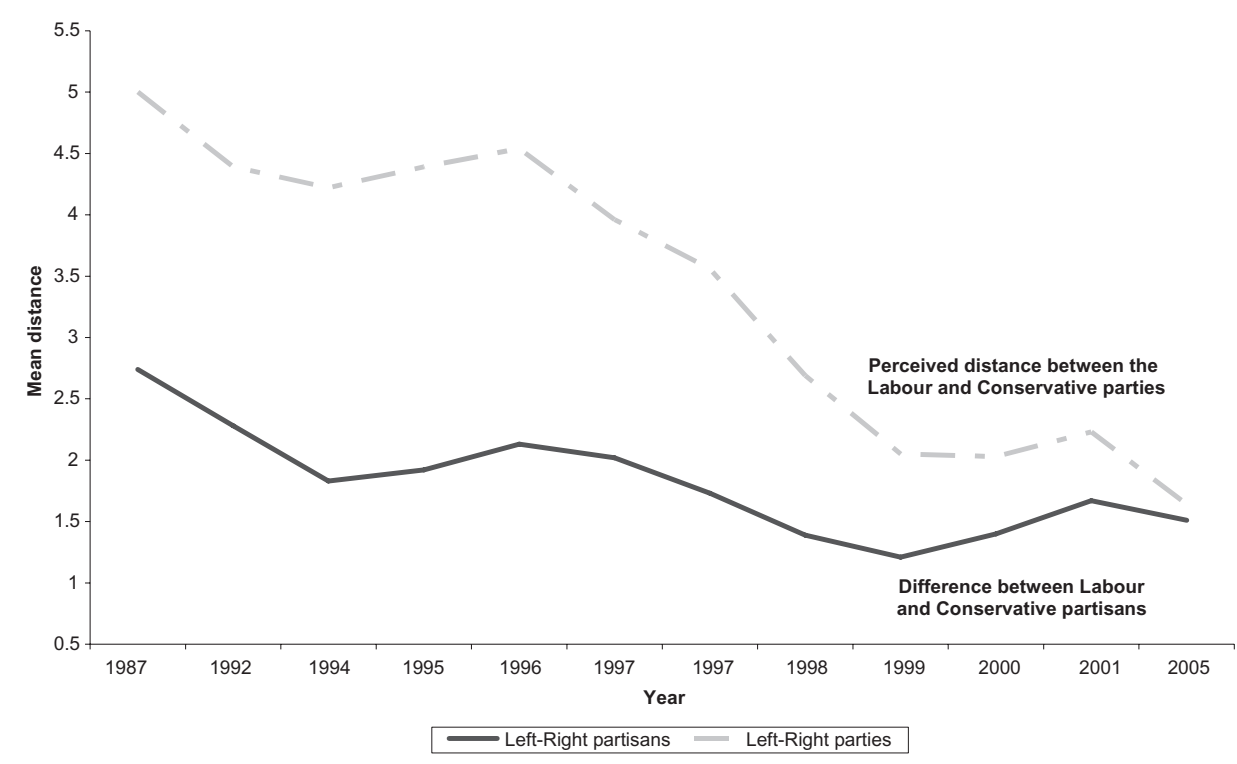


Figure 8: Comparison of the Mean Distance between Labour and Conservative Partisans and the Perceived Distance between the Labour and Conservative Parties, on the EU Scale between 1992 and 2005 (British Election Studies)

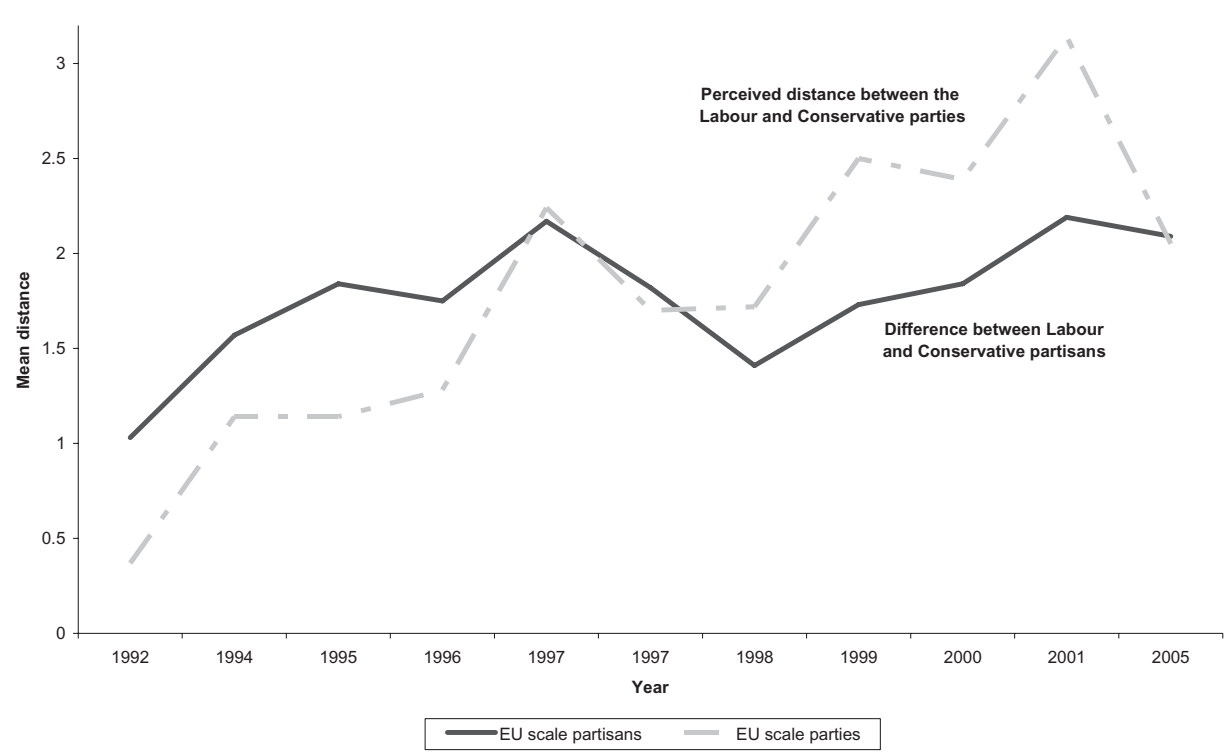

A strong relationship is evident connecting the perceived difference between the two main parties and the difference between their party identifiers on the left-right index. The less the perceived distance between the parties, the less the distance between party identifiers, and the measures appear to move synchronously, almost perfectly converging in 2005. It appears that a valence distribution among Conservative and Labour identifiers is mirrored in consensus between the two main parties. This finding confirms the views that the parties have been perceived to have become far closer on the left-right dimension. The relationship also implies either that parties are primarily responsive to the views of their supporters, consistent with the core vote theories of party competition, or that party supporters are primarily responsive to the positions of their parties. The latter would undermine those theories of party location reliant on the influence of core supporters. Evans and Andersen (2004) argue that the relationship on the left-right dimension primarily follows the latter argument, but Evans and Sarah Butt (2006) argue that on the issue of Europe, the relationship is most likely in the reverse direction - from voters to parties. Figure 8 illustrates the comparison of partisan differences and perceived party differences on the EU measures.

Once again we find that the measures of party difference and party voter difference coincide almost perfectly in the 2005 election study sample. The measures are very closely related and the distance between Labour and Conser- 
vative identifiers and the perceived distance between the Labour and Conservative parties is more consistently close over time on this issue. On the left-right index the gap narrowed, but on the EU scale the gap separating the distance between the parties and the distance between their supporters remains at around 0.5. In 1997 and 2005 election years, the difference is smallest, suggesting that in these years a similar knowledge effect more closely associates party locations with the locations of voters (see Tilly et al., 2005). The pattern is more consistent with the arguments advanced by 'core vote' explanations - that parties appeal to their existing supporters to maximise these votes. However, on the left-right dimension the trade-off is increasingly redundant.

Figures 7 and 8 do not test a causal relationship between party and voter location, but the evidence suggests that since parties and supporters converge on the left-right dimension, these left-right issues have come to resemble valence issues, whereas on the nationalist dimension, represented by the EU integration issue, competition is more likely to be positional. The findings may also signify a relationship between consensus on the left-right dimension and division on the European dimension. That is, as consensus is reached on one dimension, competition shifts to alternative dimensions to create new dividing lines for party choice. However, although the European issue has become more divided over time, it remains a very low salience issue in British political competition, whereas issues relevant to the left-right dimension remain the most salient. It is not possible to compare the salience of the above dimensions over time using the same BES surveys, ${ }^{12}$ but 'most important issue facing the country today' questions are asked consistently by MORI (see http://www.mori.com). These data demonstrate that public spending issues, health and education - more relevant to the left-right dimension - remain the two most salient issues across the 1987 to 2005 time period, but the salience of Europe has not increased in proportion to the change in the competitive nature of this issue, despite it being in the interest of the optimally situated party, in this case, the Conservatives (Evans, 2002; Green, 2005). Therefore, valence issues comprising the left-right dimension remain significant to British political competition.

The following theoretical model links the distribution of issues as valence issues to the rise of competence-based voting in British politics.

\section{An Explanatory Model of Valence Voting}

As discussed, Stokes (1963) responded to Downs (1957) by arguing that spatial models cannot explain competition on consensual 'valence issues'. This article has illustrated that such valence issues are now an important feature of British political competition. However, valence issues can be incorporated into the Downsian model (see also Davis et al., 1970; Enelow and Hinich, 1984) where this model also includes a competence component based on the evaluation that a party will deliver on an issue (Enelow and Hinich, 1982; 1984; Enelow and Munger, 1993; Heath 
et al., 2001). Such a combined model can also encompass competition on positional issues, such as European integration.

In the British context Anthony Heath et al. (2001) build a model of issue voting that takes its starting point as the formation of issue preferences for a given individual. The authors then elaborate on the spatial model including the importance of perceived party competence across issues and also the likelihood that any party can deliver on each issue. On some issues (such as crime) voters believe that no party can deliver - the issue simply is not thought to be 'influenceable' by government action. Voters base their decisions on issues where there is the biggest difference between the parties. This finding is also consistent with the argument of the direction theory of voting (MacDonald et al., 1991; Rabinowitz and MacDonald, 1989). Heath et al. also find that voters will more likely base vote decisions on issues where there is the greatest likelihood that a party will implement these policies. Therefore, some issues will not feature rationally in the utility calculation, since neither party can be expected to deliver. It can also explain why the positional component is likely to be superseded by competence evaluations across deliverable issues.

Firstly, Heath et al. (2001, pp. 160-1) argue that an individual's, $i$, issue position $P$ on dimension or issue $j\left(P_{j i}\right)$ can be predicted by socio-demographic factors, such as union membership, housing tenure and social class (denoted $A, B, C$ ). However, we can also suggest that $P_{i j}$ is influenced by the cues of the parties - as the parties converge, so do voters, and there are grounds to assume that at least some of this shift is due to a party-led process. Hence, $P_{j i}$ is a function of factors $\mathrm{A}, \mathrm{B}, \mathrm{C} \ldots$ and also of $P_{j p}$ - the position of party $p$ on dimension $j$.

$$
P_{i j}=A, B, C \ldots+P_{j p}
$$

Furthermore, combining the positional component of the traditional spatial model with the competence component found to be important to the vote choice, we can model the combined issue-based calculation of voter $i$ on dimension or issue $j$, as follows:

$$
U_{i j p}=-\left(P_{j p}-P_{j i}\right)^{2}+C_{j p}
$$

Here voter $i$ 's overall evaluation of party $p$ 's utility on dimension $j\left(U_{i j p}\right)$ depends upon the squared distance between party's position $\left(P_{j p}\right)$ and voter i's own preferred position or ideal point on this issue $\left(P_{j i}\right)$. Since the utility declines with distance, a negative sign defines this utility function. The model presented above also includes the term $C_{j p}$, which captures the competence of a party on a particular issue or dimension.

Heath et al. (2001) also model the utility to voter $i$ of supporting party $j$ as dependent on the utility calculation above and on the subjective probability that each party will deliver. In fact, this step can be encompassed in equation (2) above. If all parties are considered incapable of delivering on an issue, because that issue cannot be readily influenced by government action, then this is a constant. If 
parties are differentially capable then this element is captured in a party's perceived competence on that issue, since competence can be constructed as that party's ability to deliver.

Furthermore, we can easily incorporate different issue dimensions according to the salience of weight $w$ that voter $i$ attaches to that issue $j$ in evaluating a party (Endersby and Galatas, 1998). Hence a voter may attach more weight to an issue on which they deem parties to be capable of delivering (or because that issue is simply considered more important), so that the overall utility $U_{i p}$ depends on the weighting of different issues or dimensions (indexed 1,2), e.g. $w_{j 1} U_{i 1 p}+w_{j 2} U_{i 2 p}$.

The empirical evidence presented earlier suggests that on the left-right dimension in Britain the spatial component $\left(P_{j p}-P_{j i}\right)$ has reduced significantly over time. Furthermore, the distance between the voters of these parties has correspondingly diminished. The findings presented earlier therefore have significant implications for the vote calculation. That is, as the distance between voter and party $\left(P_{j p}-P_{j i}\right)$ is increasingly small over time, equation (2) suggests that this variable will be less deterministic of the utility calculation. Furthermore, the closer the difference between voters and parties, the greater the likelihood that $U_{i j p}=-\left(P_{j p}-P_{j i}\right)^{2}$ will be a constant value on this dimension across two parties. This effectively renders this part of the equation redundant, especially by 2005 when convergence is at its most acute, and the only variation in the calculation is to be found in $C_{j p}$. The argument is therefore as follows: if distance between the voter and the party is 0 , as parties converge upon a consensual electorate, the issue voting calculation relies upon the perceived competence of the party on the issue and the degree to which the individual perceives the issue or problem capable of being resolved by the party, rather than spatial distance. Thus competence evaluations predominate over the traditional spatial model of voting. Where issue distance is greatest, for example on the issue of Europe, a reverse calculation can be expected, though mediated for partisans by the close relationship between party and voter position over time.

Using this utility-based model we can therefore understand why, if voters and parties coalesce around the same ideological positions, as evident in valence issues, then the evaluations made by rational voters are far more likely to be competence-based. However, in the case of the European dimension, we can expect issue distance to be predictive of party support. Indeed, whereas David Sanders (1999) found lower levels of left-right ideological voting over time leading to the 1997 election, Evans (2002) witnessed a persistent ideological effect in 2001 for the EU scale. Furthermore, the finding by Clarke et al. (2004), that valence politics has increasingly come to define British voting behaviour, is consistent with this theoretical model.

\section{Implications for Party Competition}

The empirical evidence presented in this article suggests that on valence issues parties are no longer potentially constrained by their core voters, contrary to the 
assumptions of the core vote or activist theories which have sought thus to explain divergent party positions in the 1970s and the 1980s in Britain and more recently in the US. ${ }^{13}$ The narrowing of the ideological space on the left-right dimension can be offered as a potential explanation for the relative convergence of the British parties in recent elections. Furthermore, if these party supporters adopted more consensual preferences because the parties have converged, then these theories can be more fundamentally challenged. Notwithstanding this possibility, such theories currently have limited application to the British case, since the median supporters of each party no longer present a trade-off to the median voter overall.

The theoretical model can also help us better evaluate the positional and directional debate in the spatial voting literature. Whereas Stuart MacDonald et al. (1991) relate the absence of an ideological vote choice for centrist parties to a falsification of the Downsian theory (Downs, 1957), we can understand this outcome as a consequence of the proximity prediction. We can expect parties to converge, since their support base has also converged in the UK, but once they do so, the vote calculation naturally depends on components on which it is still possible to differentiate between parties. Therefore, although issue distance should be a weaker predictor of vote choice between two centrist parties, valence issues still matter to the vote choice in terms of party competence (Campbell and Meier, 1979; Clarke et al. 2004).

More fundamentally, Stokes (1963) argued that in a period of weak ideological focus, when the dominant modes of political competition are consensual, the spatial model no longer explains party competition. Nevertheless, the main implication of this article is not that spatial models do not explain party competition, rather that we need to have ways of theorising party competition when spatial models successfully predict party behaviour. That is, if voters and parties adopt a consensual position on the left-right dimension, as we have seen, then we have simply supported the prediction either that normally distributed unidimensional preferences in a two-party system create incentives for parties to converge, or/and that parties shifting towards the median voter bring sufficient numbers of their own voters to these same positions. Therefore, parties can act according to Downsian predictions. The dominance of valence issues to British political competition begs the question of how parties should rationally compete in such a valence context.

The implication of the formal model outlined above is that when voters and parties agree, as seen on valence issues, an incentive exists for parties to maximise differences in ability to deliver, or on means when parties and voters agree on ends. Where the distance between individual and party is maximised, the utility to voter $i$ of voting for party $j$ on issue $k$ will be determined by the probability that the party will deliver on that issue: competence (or 'valence'). This effectively means that for issues on which voters believe an issue is not influenceable by government action, no party can easily gain an advantage, 
because any perceived advantage is offset by the limited utility an individual expects to gain from voting for either party. However, on an issue for which a party can make an instrumental difference, an individual will derive the highest utility from the party perceived to have the best probability of implementing the issue or policy goal. We therefore need to consider how a party can influence its rating $C_{j p}$ in the above model (equation 2). Otherwise phrased, how can a party win the competence game?

A full model of the predictors of competence, the influencers on $C_{j p}$, might include incumbency advantage, retrospective ratings of delivery in government and strong leadership (Clarke et al., 2004; Stokes, 1992), but more malleable within a party's competitive strategic behaviour is the degree to which a party seeks to highlight or raise the salience of the issues on which it has a performance advantage. Therefore, the theories of issue ownership (Petrocik, 1996; Petrocik et al., 2003) and issue saliency (Budge and Farlie, 1983; Budge et al., 1987) should be the focus of further attention given their application to a 'valence politics' context. Jointly these theories suggest that political parties will try to focus elections and therefore voting decisions upon issues on which that party is perceived to be most competent, by raising the salience of issues a party 'owns'. Therefore, delivery in government, agenda focus and consistency with a party's reputation should all be important. Thus, elections become a competition between cueing and priming, rather than the agenda shaping in a traditional sense espoused by Patrick Dunleavy and Hugh Ward (1981).

However, given the focus on spatial models of competition, there has been relatively little research on the key components of the issue ownership and saliency theories of party competition. In light of the intuitive weight of spatial models of party competition it is understandable that theories of party competition outside these models are not as thoroughly examined. Yet we know little about how parties can increase the degree to which they are judged more competent or trusted to deliver on issues, to what degree parties can manipulate the basis of voting decisions to their favour or how these evaluations compare across parties and across countries. This article indicates that we can no longer account for the dominant modes of political competition within the spatial model since voters and parties increasingly agree on the most important dimension of British voting behaviour and hence we see instead a context of valence politics. There is clearly an imperative for future research in this area (see Green and Hobolt, 2006).

\section{Conclusions}

This article predicted increasingly consensual distributions of preferences among voters and closer competition between the political parties on the left-right dimension, but an opposite trend on the European issue. These expectations were confirmed. The left-right dimension exhibited growing consensus between party 
voters and between perceived party positions. This represents a trend of great significance for political competition, particularly in light of the apparent importance of valence explanations of British voting behaviour and the continued salience of valence issues. Stokes (1963) named the period wherein valence issues were common as a period of 'weak ideological focus'. The findings of this article suggest that British politics can be likewise characterised. The fact that party voters agree is offered as an important and overlooked explanation for party convergence, while also bearing in mind a causal direction from voter position to parties, and vice versa. The EU dimension appears to have shifted from a crosscutting issue, dividing supporters of all parties and none, to a more consensual distribution, and then towards a more positional distribution, whereby preferences are divided by party support. A theoretical model was offered to explain why party convergence and voter consensus on the left-right dimension leads to competence evaluations in a rational model of voting utility based on issues. Conversely, we should expect the spatial model of ideological voting to apply to the European dimension, and in so far as the spatial model may not predict vote choice as powerfully, this is not inconsistent with the precepts of Downsian competition (Downs, 1957).

In discussing implications for party strategy the main argument advanced is the need for more competence-based theories of party behaviour, specifically those based on relative issue competence evaluations (issue ownership) and salience theory. More work needs to be done to devise a theory sufficiently intuitive and testable, but the current political pattern of preferences and competition warrants such a pursuit.

The expectations of a valence electorate were framed by suggesting potential explanations for changes in preferences, namely de-alignment, party cueing and exogenous factors. Any prediction for the future of political competition and therefore the relevance of theories of party competition therefore largely rests on the testing of these causal relationships, and for this reason we should be cautious about extending the claims of 'valence politics' too far. By separating these three explanations it is not necessary to claim that each is distinct from each other. As Evans and Butt (2006, p. 211) observe, it is as though 'signals from the parties are being read by voters who in turn send their own signals back to the parties'. As parties converge so it appears that voters have in turn converged, reinforcing this trend. Conversely, as the parties have taken more clearly partisan lines on the issue of Europe, so their supporters have followed. This relationship should cause us to question, therefore, the overly simplistic rationale for the influence of existing party supporters on party position. Parties may respond to their voters' positions in the immediate term, but they may be responsible for those positions over time. Although both parties and their partisans appear to be operating in a world of 'weak ideological focus' it is too early to predict whether this situation will remain. Nevertheless, in such a period of weak ideological focus, 'It will not do simply to exclude valence- 
issues from the discussion of party competition. The people's choice too often depends on them' (Stokes, 1963, p. 373).

(Accepted: 4 July 2006)

About the Author

Jane Green, School of Social Sciences, Department of Politics, Dover Street, University of Manchester, M139PL, UK; email: jane.green@manchester.ac.uk

\section{Notes}

Thanks to Rob Ford, David Rueda, Iain McLean, Sarah Butt, Chris Wlezien, Adrian Blau, Geoffrey Evans, Gillian Peele, Bonnie Meguid, David Sanders, Sara Hobolt and to the anonymous reviewers of this journal for helpful comments on versions of this article. The usual disclaimer applies.

1 A search among all UK broadsheet newspapers in the past six years, between 2000 and 2005, produced 216 articles in which the Conservative core vote was cited as an explanation for Conservative strategy.

2 Adams, 2001; Adams and Merrill, 1999; Aldrich, 1983; 1995; Hirschman, 1970; Key, 1966; Kitschelt, 1989; 1994; McLean, 1982; May, 1972; Robertson, 1976; Schofield, 2004; 2005; Schofield et al., 2003; Schofield and Sened, 2005. A related argument is that candidates are policy-seeking and therefore pursue non-centrist positions akin to activist positions (Calvert, 1985; Chappell and Keech, 1986; Wittman, 1983).

3 Adams, 2001; Adams and Merrill, 1999; Schofield, 2003; 2004; 2005; Schofield and Sened, 2005.

4 Bara and Budge, 2001; Endersby and Galatas, 1998; Green, 2005; Heath et al., 2001; McLean, 2002.

5 In the 2001 wave of the British Election Panel Study, the association between the perceived distance between the Conservative party and the Labour party on a composite score of the difference between the placement of the two parties with responses to the question, 'Do the Conservatives and Labour differ?' was Pearson $\mathrm{Chi}^{2}=262.62$, significant at the $p<0.001$ level $(N=1,795)$. An average index of distance was computed for all five scales (work-prices, tax-spend, nationalisation-privatisation, equalise incomes and EU unite) by subtracting the perceived position of the Conservative party from the perceived position of the Labour party. This variable was correlated with responses on the 4-level variable of 'difference between the Conservatives and Labour where $1=$ great difference, 2 = same difference, $3=$ not much difference and $4=$ don't know.

6 Adams, 2001; Adams and Merrill, 1999; Aldrich, 1983; 1995; Hirschman, 1970; Key, 1966; Kitschelt, 1989; 1994; McLean, 1982; May, 1972; Robertson, 1976; Schofield, 2004; 2005; Schofield et al., 2003; Schofield and Sened, 2005.

7 Evans and Norris, 1999; Heath et al., 2001; Hindmoor, 2004; Whiteley and Seyd, 2002.

8 See Carey and Burton, 2004; Dunleavy and Ward, 1981; Maor, 1997; Riker, 1993;

9 In 2005 the question was rephrased where $0=$ definitely get out of the EU and $10=$ definitely stay in.

10 British Social Attitude (BSA) Surveys between 1995 and 2005 signify consensual voter placements. Party placement questions are not included in the BSA data.

11 In 2001 the post-election questionnaire follow-up sample $(N=1,844)$ of the BES cross-section included the scale, worded $0=$ reducing crime more important, to $10=$ rights of accused more important. On this scale statistically significant differences are only observed between Labour and Conservative identifiers, but not between these groups and Liberal Democrats or between these groups and individuals with no party identification. The difference between Labour and Conservatives was very slight in comparison to the other scales investigated in this study.

12 The importance to vote choice of the issue scales was asked in 1992 only. In 2001 respondents were asked to cite the 'most important issue in the election' and in 2005 respondents were asked to cite the 'most important issue facing the country'.

13 Adams, 2001; Adams and Merrill, 1999; Aldrich, 1983; 1995; Hirschman, 1970; Key, 1966; Kitschelt, 1989; 1994; McLean, 1982; May, 1972; Robertson, 1976; Schofield, 2004; 2005; Schofield et al., 2003; Schofield and Sened, 2005.

\section{References}

Adams, J. (2001) Party Competition and Responsible Party Government: A Theory of Spatial Competition Based upon Insights from Behavioural Voting Research. Ann Arbor MI: The University of Michigan Press.

Adams, J. and Merrill, S. III (1999) 'Modeling Party Strategies and Policy Representation in Multiparty Elections: Why are Strategies so Extreme?', American Journal of Political Science, 43 (3), 765-91. 
Aldrich, J. H. (1983) ‘A Downsian Spatial Model with Party Activism', The American Political Science Review, 77 (4), 974-90.

Aldrich, J. H. (1995) Why Parties? The Origin and Transformation of Political Parties in America. Chicago IL: The University of Chicago Press.

Aspinwall, M. (2004) Rethinking Britain and Europe: Plurality Elections, Party Management and British Policy on European Integration. Manchester: Manchester University Press.

Bara,J. and Budge, I. (2001) ‘Party Policy and Ideology: Still New Labour?’, Parliamentary Affairs, 54 (4), 590-606.

Bromley, C. and Curtice, J. (2002) 'Where Have All the Voters Gone?', in A. Park, J. Curtice, K. Thomson, L. Jarvis and C. Bromley (eds), British Social Attitudes 19th Report, London: National Centre for Social Research, pp. 141-67.

Budge, I. et al. (1987) 'The Internal Analysis of Election Programmes', in I. Budge, D. Hearl and D. Robertson (eds) Ideology, Strategy and Party Change: Spatial Analyses of Post-War Election Programmes in 19 Democracies. Cambridge: Cambridge University Press, pp. 15-38.

Budge, I. and Farlie, D. (1983) Explaining and Predicting Elections: Issue Effects and Party Strategies in Twenty-Three Democracies. London: George Allen \& Unwin.

Butler, D. and Stokes, D. (1969) Political Change in Britain: Forces Shaping Electoral Choice. London: Macmillan.

Calvert, R. L. (1985) 'Robustness of the Multidimensional Voting Model: Candidate Motivations, Uncertainty, and Convergence', American Journal of Political Science, 29 (1), 69-95.

Campbell, J. E. and Meier, K. J. (1979) 'Style Issues and Vote Choice', Political Behaviour, 1 (3), 203-15.

Carey, S. and Burton, J. (2004) 'Research Note: The Influence of the Press in Shaping Public Opinion towards the European Union in Britain', Political Studies, 52 (3), 623-40.

Chappell, H.W. and Keech, W. R. (1986) 'Policy Motivation and Party Differences in a Dynamic Spatial Model of Party Competition', The American Political Science Review, 80 (3), 881-99.

Clarke, H. D. and Stewart, M. C. (1984) 'Dealignment of Degree: Partisan Change in Britain, 1974-83', The Journal of Politics, 46 (3), 689-718.

Clarke, H., Sanders, D., Stewart, M. and Whiteley, P. (2004) Political Choice in Britain. Oxford: Oxford University Press.

Davis, O.A., Hinich, M.J. and Ordeshook, P. (1970) 'An Expository Development of a Mathematical Model of the Electoral Process', The American Political Science Review, 64 (2), 426-48.

Denver, D. (1994) Elections and Voting Behaviour in Britain. Hemel Hempstead: Harvester Wheatsheaf.

Downs, A. (1957) An Economic Theory of Democracy. New York: Harper \& Row.

Dunleavy, P. and Ward, H. (1981) 'Exogenous Voter Preferences and Parties with State Power: Some Internal Problems of Economic Theories of Party Competition’, British Journal of Political Science, 11 (3), 351-80.

Endersby, J. and Galatas, S. (1998) 'British Parties and Spatial Competition: Dimensions of Party Evaluation in the 1992 Election', Public Choice, 97 (3), 363-82.

Enelow, J. M. and Hinich, M. J. (1982) 'Nonspatial Candidate Characteristics', Journal of Politics, 44 (1), 115-30.

Enelow, J. M. and Hinich, M. J. (1984) The Spatial Theory of Voting: An Introduction. Cambridge: Cambridge University Press.

Enelow, J. M. and Munger, M. C. (1993) 'The Elements of Candidate Reputation: The Effect of Record and Credibility on Optimal Spatial Location', Public Choice, 77 (4), 757-72.

Evans, G. (1998) 'How Britain Views the EU', in R. Jowell, J. Curtice, A. Park, L. Brook, K. Thomson and C. Bryson (eds), British and European Social Attitudes: How Britain differs, The 15th Report. Aldershot: Ashgate: Social and Community Planning Research, pp. 173-89.

Evans, G. (1999) ‘Europe: A New Electoral Cleavage?’, in G. Evans and P. Norris (eds), Critical Elections: British Parties and Voters in Long-Term Perspective. London: Sage Publications, pp. 207-22.

Evans, G. (2001) 'The Conservatives and Europe: Waving or Drowning?', in R. Jowell, J. Curtice, A. Park, K. Thomson, C. Bromley, L. Jarvis and N. Stratford (eds), British Social Attitudes: the 18th Report. London: Sage, pp. 245-62.

Evans, G. (2002) 'European Integration, Party Politics andVoting in the 2001 Election', British Elections and Parties Review, 12, 95-110. 
Evans, G. and Andersen, R. (2004) 'Do Issues Decide? Partisan Conditioning and Perceptions of Party Issue Positions through the Electoral Cycle', British Elections and Parties Review, 14, 18-39.

Evans, G. and Butt, S. (2006) 'Leaders or Followers? Parties and Public Opinion on the European Union', British Social Attitudes 05/06 Report. London: Sage.

Evans, G. and Norris, P. (eds) (1999) Critical Elections: British Parties and Voters in Long-Term Perspective. London: Sage Publications.

Evans, G., Heath, A. and Lalljee, M. G. (1996) 'Measuring Left-Right and Libertarian-Authoritarian Values in the British Electorate', British Journal of Sociology, 47 (1), 93-112.

Forster, A. (2002) Euroscepticism in Contemporary British Politics. London: Routledge.

Franklin, M. and Wlezien, C. (1997) 'The Responsive Public: Issue Salience, Policy Preferences and Preferences for European Unification', Journal of Theoretical Politics, 9 (3), 347-63.

Franklin, M., Marsh, M. and McLaren, L. (1994) 'Uncorking the Bottle: Popular Opposition to European Unification in the Wake of Maastricht', Journal of Common Market Studies, 32 (4), 455-72.

Green, J. (2005) 'Conservative Party Rationality: Learning the Lessons from the Last Election for the Next', Journal of Elections, Public Opinion and Parties, 15 (1), 111-27.

Green, J. and Hobolt, S. B. (2006) 'Owning the Issue Agenda: Party Strategies and Vote Choices in British Elections', paper given at the American Political Science Association Annual Meeting, Philadelphia, USA.

Groseclose, T. (2001) 'A Model of Candidate Location When One Candidate Has a Valence Advantage', American Journal of Political Science, 45 (4), 862-86.

Heath, A., Jowell, R. and Curtice, J. (1985) How Britain Votes. Oxford: Pergamon Press.

Heath, A., Curtice, J., Jowell, R. and Evans, G. (1991) Understanding Political Change. Oxford: Pergamon.

Heath, A., Taylor, B., Brook, L. and Park, A. (1999) 'British National Sentiment', British Journal of Political Science, 29, 155-75.

Heath, A., Jowell, R. and Curtice, J. (2001) The Rise of New Labour: Party Policies and Voter Choices. Oxford: Oxford University Press.

Hindmoor, A. (2004) New Labour at the Centre. Oxford: Oxford University Press.

Hirschman, A. (1970) Exit, Voice and Loyalty. Cambridge MA: Harvard University Press.

Key, V. O. (1966) The Responsible Electorate. Cambridge MA: Belknap Press of Harvard University Press.

Kirchheimer, O. (1966) ‘The Transformation of the Western European Party Systems', in J. LaPalombara and M. Weimer (eds), Political Parties and Political Development. Princeton NJ: Princeton University Press, pp. 177-200.

Kitschelt, H. (1994) The Transformation of European Social Democracy. Cambridge: Cambridge University Press.

Kitschelt, H. (1989) The Logics of Party Formation: Ecological Politics in Belgium and West Germany. Ithaca NY: Cornell University Press.

MacDonald, S. E., Listhaug, O. and Rabinowitz, G. (1991) 'Issues and Party Support in Multiparty Systems', The American Political Science Review, 85 (4), 1107-31.

MacDonald, S. E. and Rabinowitz, G. (1998) 'Solving the Paradox of Nonconvergence:Valence, Position, and Direction in Democratic Politics', Electoral Studies, 17 (3), 281-300.

McLean, I. (1982) Dealing in Votes. Oxford: Martin Robertson.

McLean, I. (2002) 'William H. Riker and the Invention of Heresthetic(s)', British Journal of Political Science, 32 (3), $535-58$.

McLean, I. and Jennings, C. (2006) Applying the Dismal Science: When Economists Give Advice to Government. Basingstoke: Palgrave Macmillan.

Maor, M. (1997) Political Parties and Party Systems: Comparative Approaches and the British Experience, Theory and Practice in British Politics. London: Routledge.

May, J. (1972) 'Opinion Structure of Political Parties: The Special Law of Curvilinear Disparity', Political Studies, 22 (2), 135-51.

Panebianco, A. (1988) Political Parties: Organization and Power. Cambridge: Cambridge University Press.

Petrocik, J. (1996) 'Issue Ownership in Presidential Elections, with a 1980 Case Study', American Journal of Political Science, 40 (3), 825-50. 
Petrocik, J., Benoit, W. and Hansen, G. (2003) 'Issue Ownership and Presidential Campaigning, 1952-2000', Political Science Quarterly, 118 (4), 599-626.

Pierce, J. C. (1970) 'Party Identification and the Changing Role of Ideology in American Politics', Midwest Journal of Political Science, 14 (1), 25-42.

Przeworski, A. and Sprague, J. D. (1986) Paper Stones: A History of Electoral Socialism. Chicago IL: University of Chicago Press.

Rabinowitz, G. and MacDonald, S. E. (1989) 'A Directional Theory of Issue Voting', American Political Science Review, 83 (1), 93-122.

Riker, W. H. (1993) 'Rhetorical Interaction in the Ratification Campaigns', in W. H. Riker (ed.), Agenda Formation. Ann Arbor MI: University of Michigan Press, pp. 81-123.

Robertson, D. (1976) A Theory of Party Competition. London: John Wiley \& Sons.

Sanders, D. (1999) 'The Impact of Left-Right Ideology', in G. Evans and P. Norris (eds), Critical Elections: British Parties and Voters in Long-Term Perspective. London: Sage Publications.

Sartori, G. (1976) Parties and Party Systems: A Framework for Analysis. Cambridge: Cambridge University Press.

Schofield, N. (2003) 'Valence Competition in the Spatial Stochastic Model', Journal of Theoretical Politics, 15 (4), 371-83.

Schofield, N., Miller, G. and Martin, A. (2003) 'Critical Elections and Political Realignments in the USA: 1860-2000', Political Studies, 51, 217-40.

Schofield, N. (2004) 'Equilibrium in the Spatial "Valence” Model of Politics', Journal of Theoretical Politics, 16 (4), $447-81$.

Schofield, N. and Sened, I. (2005) 'Modeling the Interaction of Parties, Activists and Voters: Why is the Political Center so Empty?', European Journal of Political Research, 44 (3), 355-90.

Stokes, D. E. (1963) ‘Spatial Models of Party Competition', The American Political Science Review, 57 (2), 368-77.

Stokes, D. E. (1985) 'The Paradox of Campaign Appeals and Election Mandates', Proceedings of the American Philosophical Society, 129 (1), 20-5.

Stokes, D. E. (1992) 'Valence Politics', in D. Kavanagh (ed.), Electoral Politics. Oxford: Clarendon Press, pp. 141-64.

Tilly, J., Andersen, R. and Heath, A. (2005) 'Political Knowledge and Enlightened Preferences - Party Choice Through the Electoral Cycle', British Journal of Political Science, 34, 285-302.

Webb, P. and Farrell, D. (1999) 'Party Members and Ideological Change', in G. Evans and P. Norris (eds), Critical Elections: British Parties and Voters in Long-Term Perspective. London: Sage Publications, pp. 44-63.

Whiteley, P. (1984) 'Perceptions of Economic Performance and Voting Behavior in the 1983 General Election in Britain', Political Behaviour, 6 (4), 395-410.

Whiteley, P. and Seyd, P. (2002) High-Intensity Participation: The Dynamics of Party Activism in Britain. Ann Arbor MI: The University of Michigan Press.

Wittman, D. (1983) 'Candidate Motivation: A Synthesis of Alternative Theories', The American Political Science Review, 77 (1), 142-57.

Zaller, J. (1992) The Nature and Origins of Mass Opinion. Cambridge: Cambridge University Press. 